\title{
カルコゲン元素 $(\mathrm{S}, \mathrm{Se}, \mathrm{Te})$ の新規な異常原子価, ジカチオンの化学
}

\author{
藤 原尚*.古川尚 道* \\ Chemistry of Dications as a Novel Unusual Valency of Chalcogen \\ Elements (S, Se, Te)
}

Hisashi Fujihara* and Naomichi Furukawa*

\begin{abstract}
Dications bonded by two positively charged heteroatoms have received a little attention, and study of their properties is of great interest. This article presents the preparation, structure, and properties of $\sigma$-bonded dications from the medium-sized cyclic compounds containing S, Se and Te atoms. Both the oxidation of 1,5-dithiacyclooctane (1,5-DTCO), the related selenium and tellurium derivatives (1,5-DSeCO, 1,5-DTeCO), and their dibenzocyclooctane derivatives using either concd $\mathrm{H}_{2} \mathrm{SO}_{4}$ or oxidizing agent such as $\mathrm{NOBF}_{4}$ and the treatment of their monooxide in concd $\mathrm{H}_{2} \mathrm{SO}_{4}$ or with $\left(\mathrm{CF}_{3} \mathrm{SO}_{2}\right)_{2} \mathrm{O}$ revealed the formation of dications containing transannular bond between two heteroatoms. The structures of the dication salts of 1,5-DTCO and 1,5-DSeCO were determined by X-ray crystallographic analysis. These dications act as an oxidant or as an electrophile depending on the added reagents. These new species are of particular interest and become attractive if one could prepare the analogous derivatives bearing multiheteroatoms. As typical example, inspection of the spectrum of the dication of the tris-sulfide, 1,11-(methanothiomethano) $-5 \mathrm{H}, 7 \mathrm{H}$-dibenzo $[b, g][1,5]$ dithiocin, and its oxides in concd $\mathrm{D}_{2} \mathrm{SO}_{4}$ indicated that the central sulfur atom should have a hypervalent bonding structure composed of two sulfur and two carbon ligands $i . e ., 10-S-4\left(\mathrm{C}_{2} \mathrm{~S}_{2}\right)$.
\end{abstract}

Key words : Heteroatom; Cation radical; Dication; Hypervalent; Unusual valency ; Transannular interaction ; Electrochemical oxidation ; Cyclic trissulfide ; Cyclic bisselenide ; Cyclic bistelluride.

\section{1. はじめに}

分子内にへテロ原子 $(\mathrm{N}, \mathrm{S})$ を 2 個含む中員環状化合 物, 特に 8 員環では 1,5-位の原子同士での渡環相互作 用 (Transannular interaction)の強いことが知られてい $る^{1,2)}$ 。例えば，硫黄原子間の渡環相互作用によるカチ オン種の安定化が1,5-ジチアシクロオクタン (1,5-DTCO:1)の電極酸化に見られる。即ち $1,5-$

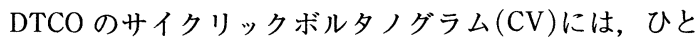
つの酸化ピークのみが観測され, 酸化電位は+0.34 V $\left(\mathrm{Ag} / 0.1 \mathrm{M} \mathrm{AgNO}_{3}\right)$ と一般のスルフィドよりも約 $0.8 \sim 1$

* 筑波大学化学系

* Department of Chemistry, University of Tsukuba, (D)
$\mathrm{V}$ も低く，その酸化還元過程は可逆である ${ }^{3)}$ 。通常ジア ルキルスルフィドの電極酸化は不可逆である。この 1,5-DTCO に見られる電極酸化の異常性は次のように考 えられる。即ち，1,5-位の硫黄原子同士の lone-pair lone-pair 相互作用の強いことは光電子スペクトル (photoelectron spectrum)より明らかで，1,5-DTCO は酸 化され易くなっており，一電子酸化により生じたカチオ ンラジカル $\left(1,5-\right.$ DTCO $\left.^{+}\right)$は二中心三電子結合 $(2$ - center 3-electron bond)を形成し安定化をうけるが, さらに電 極表面で酸化が進み安定な二中心二電子結合 $(2$ - center 2-electron bond)をもつジカチオン $\left(1,5-\mathrm{DTCO}^{2+}\right)$ を生成

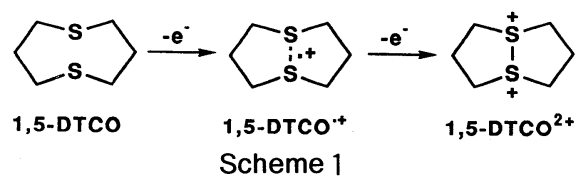




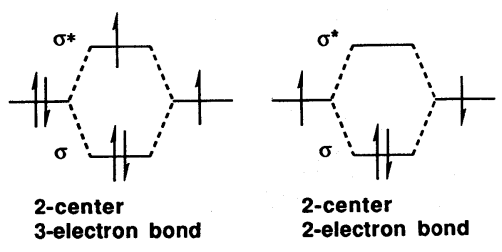

Fig. 1

する(スキーム 1)(図 1)。1,5-DTCO の CV の詳細な解 析より 1,5-DTCO ${ }^{+}$と 1,5-DTCO ${ }^{2+}$ との電位差は約 20 $\mathrm{mV}$ である。これは 1,5-DTCO から 1,5-DTCO++ への電 子移動よりも 1,5-DTCO ${ }^{+}$から 1,5-DTCO ${ }^{2+}$ への電子移 動がより容易であることを示す。これらのカチオンラジ カルおよびジカチオン塩は一電子酸化剂 $\left(\mathrm{NOBF}_{4}\right)$ を用い る一電子および二電子酸化により得られる4)。1,5-DT$\mathrm{CO}$ の二中心三電子結合については，水溶液のパルスラ ジオリシス法を用いて, $\mathrm{OH}$ ラジカルによる一電子酸化 で生成するジアルキルスルフィドのカチオンラジカルの 性状が詳しく研究されており,この結合は 2 個の $\sigma$ 電 子と 1 個の $\sigma^{*}$ 電子からなり, そのエネルギー状態は図 1 のように示され, UV 吸収バンドは $\sigma-\sigma^{*}$ 遷移に対応 することが知られている5)。

ところで, 1,5-DTCO 誘導体(スルホキシド, スルフィ ルイミン, スルホニウム塩)の X 線回折の結果は硫黄-硫 黄原子間渡環相互作用の存在を示寸(表 1)。表からわか るように 1 位の硫黄原子に電子吸引性基が置換すると $\mathrm{S}_{1}-\mathrm{S}_{2}$ の距離が硫黄原子の van der Waals 接触距離 $(3.7 \AA)$ より短く, X $\cdots . . . .5$ の 角度はほほ $180^{\circ}$ と直線を 示し $S_{1}$ の立体配置は hypervalent 構造が示唆される6)。 1,5-DTCO のモノスルホキシド( 2 ) と濃硫酸との反応で は, ${ }^{1} \mathrm{H},{ }^{13} \mathrm{C}-\mathrm{NMR}$ スペクトルおよび同位体実験より, ジ チアジカチオンの生成を確認し, 濃硫酸溶液を無水ジエ チルエーテルで処理することによりジチアジカチオン塩 を白色の粉末状結晶として得た $(\text { スキーム } 2)^{7 \sim 9)}$ 。

Table 1 Transannular S...S interaction in 1,5 -DTCO derivatives.

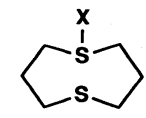

\begin{tabular}{c|c|c}
\hline $\mathrm{X}$ & $\mathrm{S} \cdots \mathrm{S}(\AA)$ & $\mathrm{X}-\mathrm{S} \cdots \mathrm{S}\left({ }^{\circ}\right)$ \\
\hline $\mathrm{NTs}^{\text {a) }}$ & 3.143 & 177.8 \\
$\mathrm{CH}_{3}{ }^{\text {b) }}$ & 3.259 & 174.0 \\
$\mathrm{O}^{\text {c) }}$ & 3.175 & 176.9 \\
\hline
\end{tabular}

a) Sulfilimine b) Sulfonium salt c) Sulfoxide

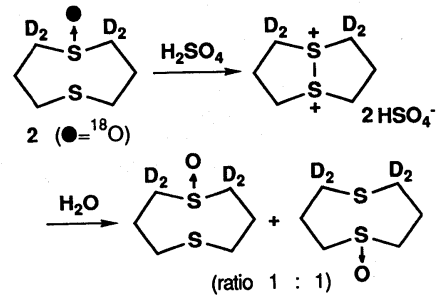

Scheme 2

以上述べたように S-S 間で $\sigma$ 結合形成するジチアジ カチオンは二電子酸化 (スキーム 1) または硫黄原子上で の置換反応 (スキーム 2 または下記に述べるスキーム 3 ) により得ることができる。ところがこれらのジカチオン 塩(アニオンが $\mathrm{BF}_{4}^{-}, \mathrm{HSO}_{4}^{-}$) は, $\mathrm{X}$ 線回折を行うことが できなかった。最近筆者らは, スルホキシド 2 とトリフ ルオロメタンスルホン酸無水物, $\left(\mathrm{CF}_{3} \mathrm{SO}_{2}\right)_{2} \mathrm{O}$, との反 応により安定な結晶を得, $\mathrm{X}$ 線結晶解析により, 硫黄一 硫黄原子間で $\sigma$ 結合を持つジカチオン塩の構造を初め て明らかにした ${ }^{10)}$ 。このジカチオン塩は隣接するへテロ 原子同士がカチオンという今までにない構造のもので, ひとつの異常原子価( unusual valency)である。なお， セ レン, テルル原子についてはその存在すら提唱されてい なかった。本稿は, 第 16 族元素である硫黄, セレン, テルルのジカチオン生成, 構造㧍よび反応性について, 筆者らの最近の研究結果を主に紹介する。

$$
\text { 2. ジチアジカチオン }\left(>S^{+}-S^{+}<\right)
$$

2.1. 1,5-DTCO ジカチオン塩の生成と構造 1,5DTCO の安定なジチアジカチオン塩(3)は無水塩化メチ レン中ー $20^{\circ} \mathrm{C}$ でスルホキシド 2 と $\left(\mathrm{CF}_{3} \mathrm{SO}_{2}\right)_{2} \mathrm{O}$ との反応 により無色の結晶として得られる $(\text { スキーム } 3)^{11)}$ 。この

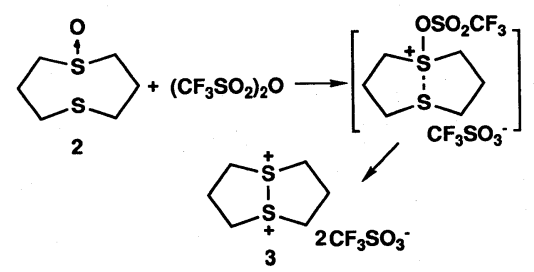

Scheme 3

反応は中間体にトリフルオロメタンスルホニルオキシス ルホニウム塩が生じ 5 位の硫黄原子による渡環反応によ りジカチオン生成へと進行し, $\mathrm{CF}_{3} \mathrm{SO}_{3}{ }^{-}$の塩基性が非常 に弱いため $\sigma$ 位のプロトン引き抜きは起こらず，転位 生成物は全く得られない。一方, 2 と無水酢酸との反応 では Pummerer 転位生成物を与える(スキーム 4$)^{12)}$ 。 


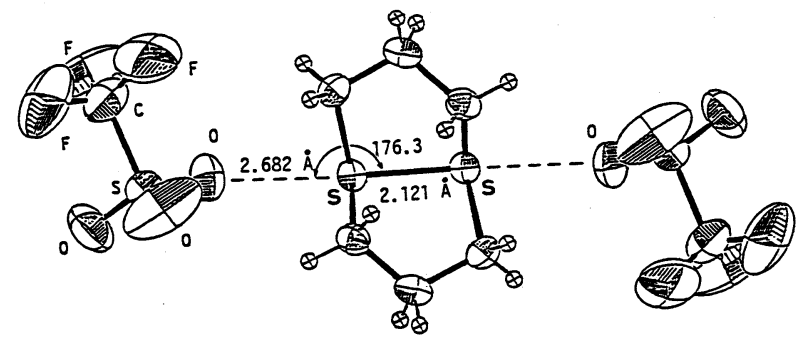

Fig. 2<smiles>O[S]1CCCSCCCS1</smiles>

2<smiles>COOCC1CSCCCC(OC(C)=O)SC1</smiles>

Scheme 4
ジカチオン塩 3\{1,5-dithioniabicyclo[3.3.0]octane bis (trifluoromethanesulfonate) $\}$ の X 線結晶構造は ${ }^{13)}$, 図 2 に示すように, $\mathrm{S}(1)-\mathrm{S}(2)$ の距離は $2.12 \AA$ と通常のジス ルフィド(RS-SR)の結合距離 $2.08 \AA$ より僅かに長いが 明らかに $\mathrm{S}^{+}-\mathrm{S}^{+}$結合が形成されている。 8 員環の立体配 座は非常に歪んだ chair-chair 形である。この塩の興味 深い点はジカチオン $\left(\mathrm{S}^{+}-\mathrm{S}^{+}\right)$とアニオン $\left(\mathrm{CF}_{3} \mathrm{SO}_{3}{ }^{-}\right)$との 極めて強い $\mathrm{S} \cdots \mathrm{O}$ 相互作用にあり, その距離は $2.68 \AA$ と van der Waals 接触距離 $(3.25 \AA)$ より非常に短く, $\mathrm{S}^{+}-\mathrm{S}^{+}$ …Oの角度は $176.3^{\circ}$ とほぼ直線であり, hypervalent 型 硫黄化合物に見られる構造をしている。

2.2. 反応性 ジチアジカチオン塩 3 の反応として は, 主に3つのタイプが考えられる。i）求核剤による $\mathrm{S}^{+}$原子上への置換反応, ii)塩基等による $\alpha$-プロトン の引き抜き反応，iii)それらによる電子移動反応である。 実際, ジカチオン塩 3 は親電子剂または酸化剂として作 用することが判った ${ }^{14,15,18)}$ 。

3 の反応で最も興味深いのは塩基との反応である。通 常スルホニウム塩は塩基との反応でイリドを生じること は良く知られている $(\text { スキーム } 5)^{16)}$ 。ところが驚くべき

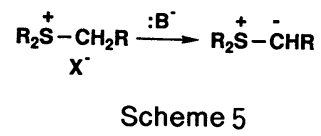

ことに，3とフルオレニルアニオン (4) との反応では, $\alpha$-位のプロトン引き抜き反応は起こらず, 酸化還元反 応による生成物を得た $(\text { スキーム 6 })^{17)}$ 。本反応は 9-メシ チルフルオレニルリチウム $(5$ ) と 3 との反応により，9-
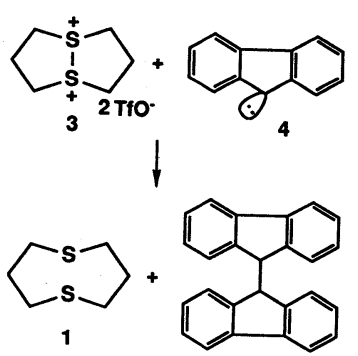

Scheme 6

メシチルフルオレニルラジカルの生成を UV スペクトル により検出し, カルバニオン 4 から 3 への一電子移動に より進行していることが判った。即ちフルオレニルアニ オン 4 は塩基としてではなく電子供与体として作用して いる。このような塩基による 3 の還元反応は $\mathrm{NaOMe}$, $\mathrm{KOBu}^{t}, \mathrm{LiBu}^{t}, \mathrm{LiNPr}_{2}-i$ を用いたときにも見られ，3の $\alpha$ 位を重水素化した $3 \mathrm{a}$ との反応においても還元生成物 $1 \mathrm{a}$ に H-D 交換は全く見られず(スキーム7), 本反応も 電子移動過程を経て進行していると考えられる。

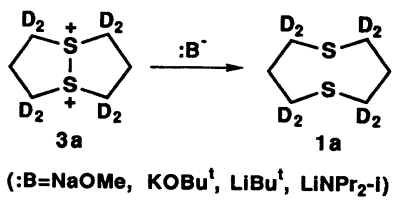

Scheme 7

\section{3. 環状トリススルフィドのジカチオン}

中員環状ビススルフィドの渡環反応 (transannular reaction)より誘起されるジカチオン生成は multicenter での S-S 相互作用に興味がもたれるが, 筆者らの研究 までその報告例はなかった19)。

3.1. 非環状トリススルフィドにおける S-S-S 相互作 用 2,6-ビス(メチルチオメチル)フェニルフェニルス ルフィド $(6)$ を合成し，6および類似体の電極酸化を 


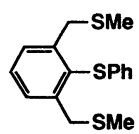

6

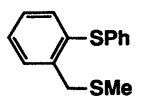

7

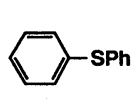

8

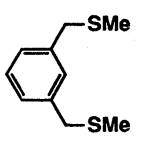

$\mathrm{CV}$ を用い行ったところ，6の酸化電位 (Ep vs. SCE) は 分子内 S-S-S 相互作用により他のスルフィド 7, 8, 9 よ り低い[Ep; $6: 1.15 \mathrm{~V}, 7: 1.34 \mathrm{~V}, 8: 1.55 \mathrm{~V}, 9: 1.82$ $\mathrm{V}]^{20)}$ 。

化合物 6 のスルホキシド(10)はX 線結晶解析より $\mathrm{S}$ (1) と $\mathrm{S}(2)$ の距離が $3.47 \AA$ と $\mathrm{S}-\mathrm{S}$ van der Waals 半径の 和より短く相互作用し易い位置にある $(\text { 図 3 })^{21)}$ 。10 の濃 硫酸溶液の ${ }^{1} \mathrm{H}-\mathrm{NMR}$ スペクトルはジカチオン 11 の生成 を示し, 後に加水分解すると, ベンジル側の硫黄原子が 酸化されたスルホキシド(12), ビススルホキシド(13)お よびスルフィド 6 がほぼ定量的に生成比 $6: 1: 1$ で得ら れる $(\text { スキーム } 8)^{20)}$ 。また，スルホキシド 12 の濃硫酸 溶液も同様の結果を示す。

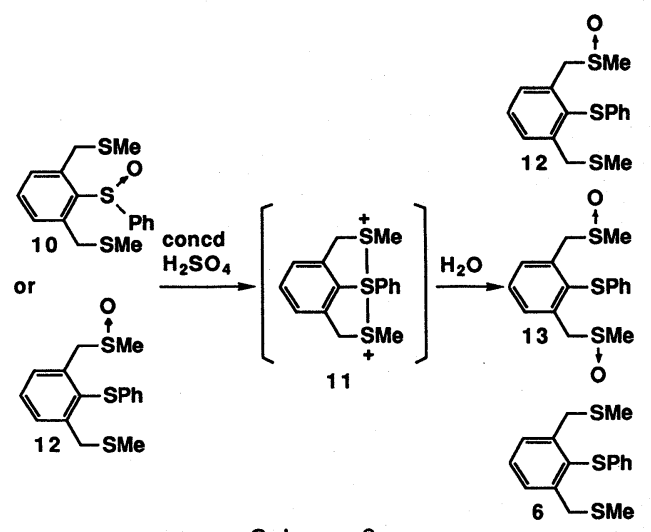

Scheme 8

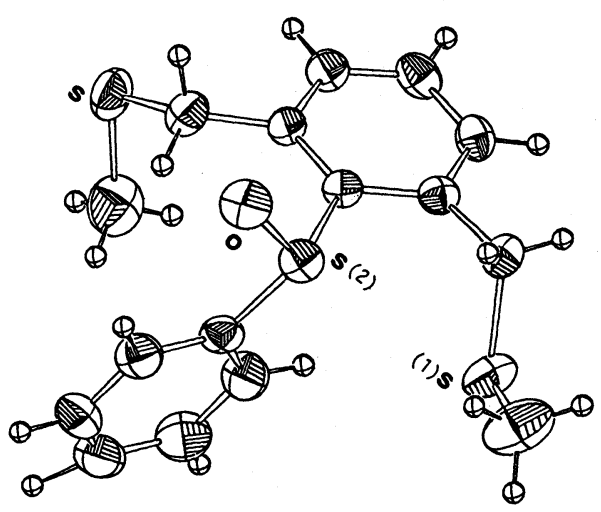

Fig. 3
3.2. 芳香環を有する環状トリススルフィドのジカチオ ン 分子内硫黄原子 3 個の相互作用をより明確にする ために，ジチア[3.3]メタシクロファンのベンゼン環を 硫黄原子で架橋した，1，11-(メタノチアメタノ)-5 H, $7 H$-ジベンゾ $[\mathrm{b}, \mathrm{g}][1,5]$ ジチオシン(14)を合成した ${ }^{22)}$ 。 14 の X 線結晶解析より 8 員環は chair-chair 形である

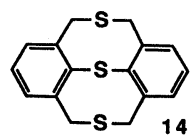

(図 4) ${ }^{21)}$ 。また, 14 の重クロロホルム中の ${ }^{1} \mathrm{H}-\mathrm{NMR}$ スペ クトルはメチレンプロトンが $\delta 3.89,4.94(\mathrm{~J}=14 \mathrm{~Hz})$ に 一組の $\mathrm{AB}$ カルテットとして現れ chair-chair 形を示す。 スルホキシド(15)の ${ }^{1} \mathrm{H}-\mathrm{NMR}\left(\mathrm{CDCl}_{3}\right)$ はメチレンプロ トンが $\delta 3.87,4.93(\mathrm{~J}=14 \mathrm{~Hz})$ と $\delta 4.29,5.54(\mathrm{~J}=12$ $\mathrm{Hz})$ に 2 組の $\mathrm{AB}$ カルテットとして観測され立体配座は chair-chair 形である。ところが, 15 の濃硫酸 (concd. $\left.\mathrm{D}_{2} \mathrm{SO}_{4}\right)$ 溶液の NMR スペクトルを測定したところ, クロ ロホルム溶液のスペクトルとは異なり, ${ }^{1} \mathrm{H}-\mathrm{NMR}$ はメチ レンプロトンが boat-boat 形構造を示す 1 組の $\mathrm{AB}$ カル テットとして $\delta 4.11,4.63(\mathrm{~J}=17 \mathrm{~Hz})$ に現れ, ${ }^{13} \mathrm{C}-\mathrm{NMR}$ においてはメチレン炭素が $\delta 40.1,64.9\left(\mathrm{CDCl}_{3}\right)$ から 1 本のピークとして $\delta 43.6\left(\mathrm{D}_{2} \mathrm{SO}_{4}\right)$ に観測され, S-S-S 相 互作用によるジカチオン $(14 \mathrm{a})$ の生成を示した(スキー ム 9$)^{22)}$ 。15 の濃硫酸溶液を加水分解すると驚くべきこ とに得られたモノスルホキシドは(16)のみであった。こ のように 3 個の硫黄原子をベンゼン環で固定すると, 攻 撃点がアルキル型硫黄(スキーム 8)からアリール型硫黄 原子に変化することが判った。同様のジカチオン生成は

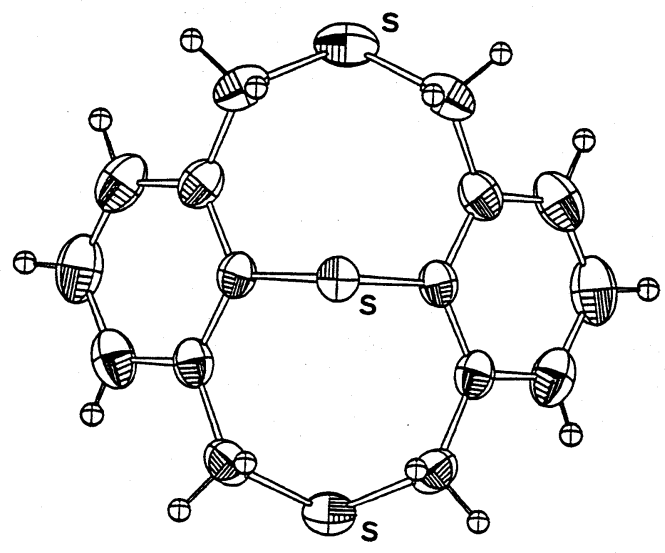

Fig. 4 


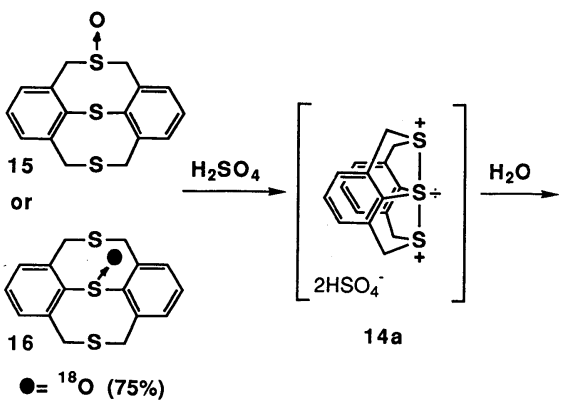

Scheme 9

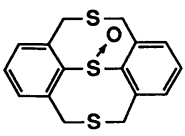

${ }^{18} \mathrm{O}(0 \%)$

スルホキシド 16 の濃硫酸溶液においても確認し, さら に 16 の酸素を ${ }^{18} \mathrm{O}$ で標識し, 同様の処理を行うと酸素 は完全に ${ }^{16} \mathrm{O}$ に変換しており，16 は濃硫酸中ではプロ トン化した後ジカチオン $14 \mathrm{a}$ をちえることは明らかで ある。

ジカチオン塩はスルフィド 14 と濃硫酸との反応溶液 をエーテルで沈澱させる方法および $\mathrm{NOPF}_{6}$ を 2 当量用 いる二電子酸化により得られるがいずれもスペクトル測 定が困難であり，(スキーム 10)に示す方法により安定 なジカチオン塩を得た。これらの塩も加水分解後はスル ホキシド 16 のを与える。

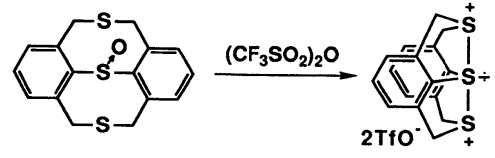

Scheme 10

ところが(スキーム 8)に示す結果，および(スキーム 11)に示すジベンゾジチオシンのスルホキシド(17, 18) の濃硫酸溶液もジカチオン $(19)$ を生成，加水分解後はべ ンジル側の硫黄原子が酸化されたスルホキシド(18)のみ を与える $(\text { スキーム 11) })^{8)}$ 。れに反し, ジカチオン $14 \mathrm{a}$

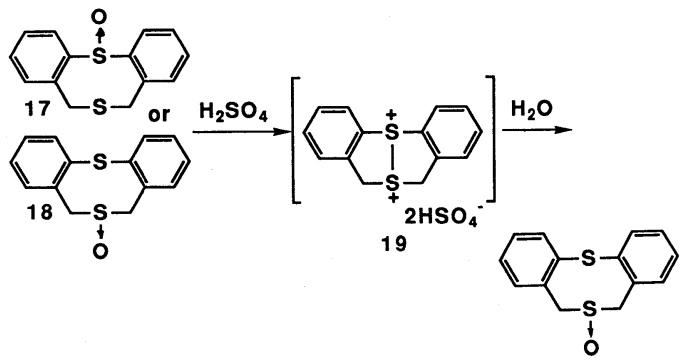

Scheme 11
と水との反応は全て, スルホキシド 16 のみである。こ れはジカチオン 14 aにおいてアリール型硫黄原子上の スルフラン型 hypervalent 結合はベンゼン環の $\pi$ 電子と ほほ直交した型をとっている。従って 14 a は 19 とは異 なり固定された構造であり,アリール型の硫黄原子は $\pi$ 軌道との重なりができないので正電荷がより高くなり, 水の攻撃を優先的に受けると考えられる。

ジカチオン $14 \mathrm{a}$ の生成は環内にジスルフィド鎖を 2 個持つトリチオニン誘導体 $(20)$ と濃硫酸または $2 \mathrm{NOPF}_{6}$ との反応においても，2 個の硫黄原子の脱硫を伴う反応 として見いだされた $(ス キ ー ム 12)^{23)}$ 。

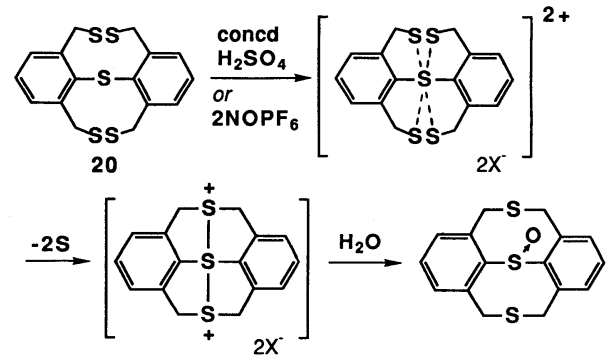

Scheme 12

化合物 14 を基本骨格とする化合物群の例として，ジ ベンゾジチオシンを二重結合で架橋した，1，11-( エテ ノ) $-5 H, 7 H$-ジベンゾ $[\mathrm{b}, \mathrm{g}][1,5]$ ジチオシン (21)を 合成した ${ }^{24)}$ 。21のX 線結晶解析より 8 員環は chair 形で あり, 二重結合の C-C 距離は $1.36 \AA$ で通常のオレフィ ンより僅かに長い(図 5) ${ }^{25)}$ 。

スルフィド 21 の concd. $\mathrm{D}_{2} \mathrm{SO}_{4}$ 溶液の高分解能 ${ }^{1} \mathrm{H}$, ${ }^{13} \mathrm{C}-\mathrm{NMR}$ スペクトルは, ジカチオン (22)の生成を示し,

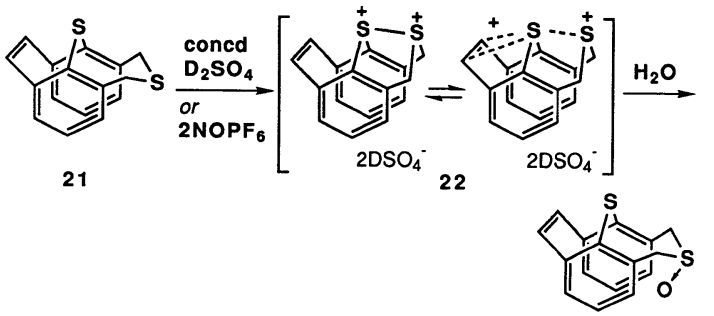

Scheme 13

23

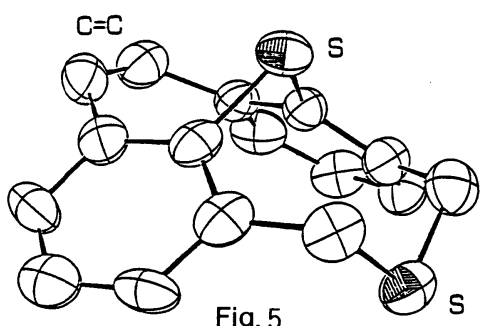

Fig. 5 


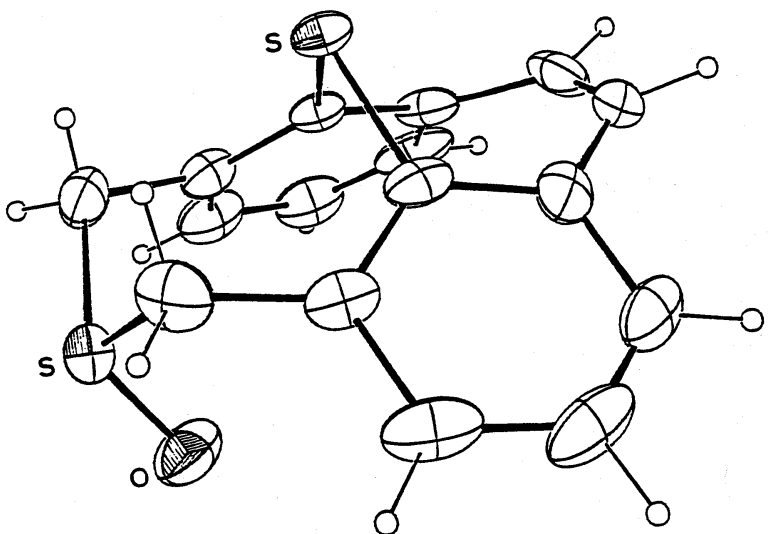

Fig. 6

この溶液の加水分解生成物はモノスルホキシド(23)のみ である ${ }^{24)} 。 23$ は X 線結晶解析より endo 体(図6)である ことから ${ }^{25)}$, ジカチオン 22 の生成が支持される。

さらにジカチオン 22 は 21 とメタクロロ過安息香酸 $(m \mathrm{CPBA})$ との酸化反応により得られるスルホキシドの exo 体-23 あるいは endo 体-23 から濃硫酸との反応にお いても生成するが加水分解生成物はいずれの場合も

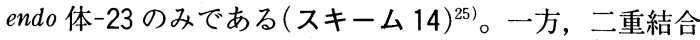
の無いジベンゾジチオシン 24 は濃硫酸で分解する。こ れらの結果より, ジカチオン 22 は $\mathrm{p} \pi^{-}\left(\mathrm{S}^{+}-\mathrm{S}^{+}\right)$相互作 用により安定化していることが考えられる。

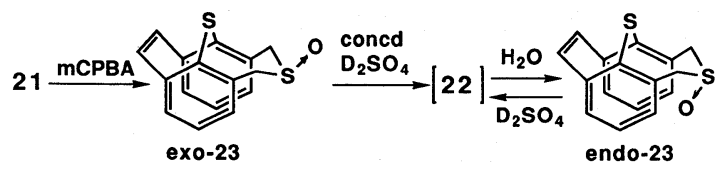

Scheme 14

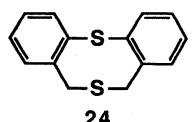

ジカチオン $14 \mathrm{a}$ の中心硫黄原子はスルフラン型 hypervalent 結合からなり，アピカル位は硫黄原子であ る。一般に硫黄原子の超原子価化合物, スルフラン (sulfurane)はアピカル位が電気陰性基の酸素原子, 卜 リフルオロメチル基からなるが26)，14a はスルフランと しては新規な構造である。一方, アピカル位が窒素原子

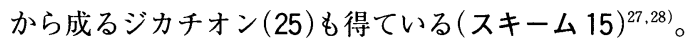
化合物 26 は $t$-BuOCl との反応で 6 配位有機硫黄化合物 (27)を与える $(\text { スキーム 16) })^{29)}$ 。27 のようにアピカル位 が窒素原子からなる高配位ジクロロジアザスルフランは

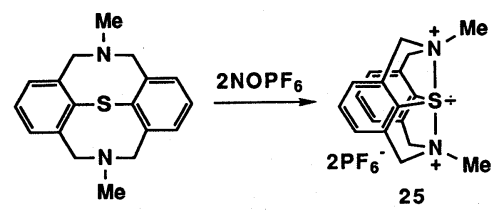

Scheme 15

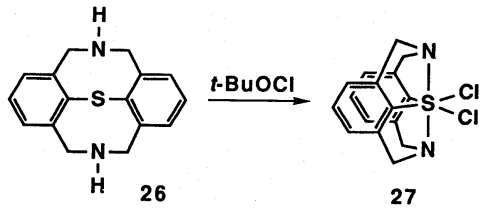

Scheme 16

初めての例である。

3.3. 脂肪族トリススルフィドのジカチオン $3,7,9-$

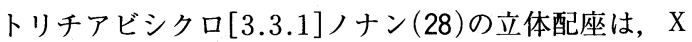
線結晶解析(図 7)および重クロロホルム中での高分解能 'H-NMR スペクトルより chair-chair 形であることが<smiles>C1CSCCS1</smiles>

判った ${ }^{30)}$ ○イクリックボルタノグラム $(\mathrm{CV})$ より, 28

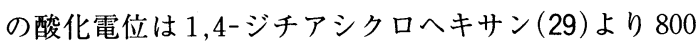
$\mathrm{mV}$ も低く，通常のアルキルスルフィドや 29 よりも酸 化され易い。このことは, 分子内の 3 個の硫黄原子によ る $\mathrm{S}-\mathrm{S}$ 相互作用に起因している。高分解能 ${ }^{1} \mathrm{H}$,

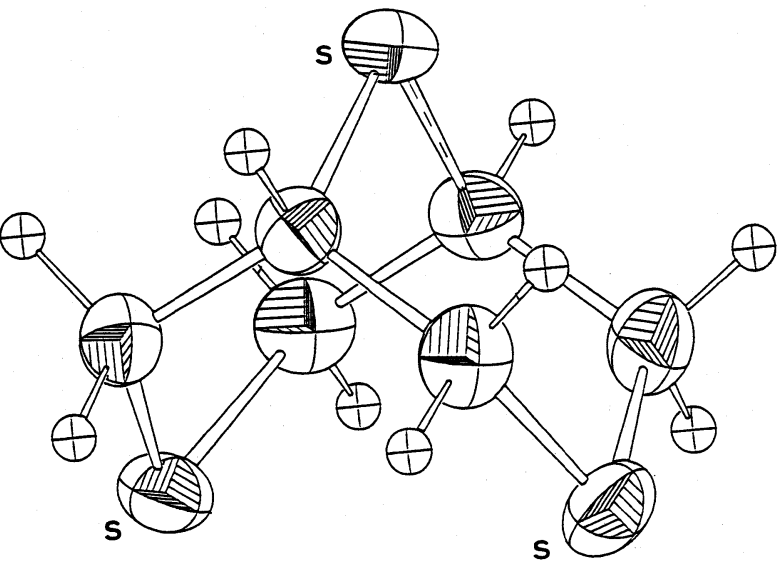

Fig. 7 
${ }^{13} \mathrm{C}-\mathrm{NMR}$ スペクトルより 28 は濃硫酸中でジカチオン (30)を生成しこれは $30 \mathrm{a}$ と $30 \mathrm{~b}$ との平衡にあり, 加水 分解後はスルホキシド(31)を与える(スキーム 17) ${ }^{30)}$ 。 スルホキシド 31 の $\alpha$ 位を重水素化した $31 \mathrm{a}$ の濃硫酸溶 液を加水分解するとスルホキシド $31 \mathrm{a}$ および $31 \mathrm{~b}$ を生 成比 $1: 1$ で与える(スキーム 18)。一方, ビススルフィ ド 29 は濃硫酸とは全く反応しないことより, ジカチオ ン生成に 3 個の硫黄原子が関与していることは明らかで ある。

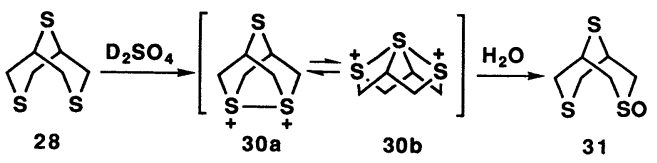

Scheme 17

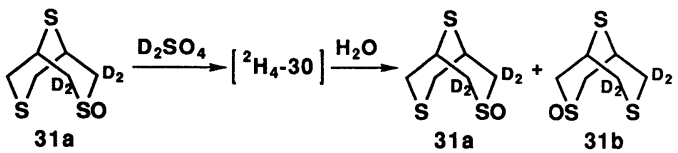

Scheme 18

ノナン系におけるジカチオン塩はスルホキシド 31 と トリフルオロメタンスルホン酸無水物との反応により得 られた

\section{4. 非平面性芳香族ビススルフィドの ジカチオン}

カルコゲン元素を含む平面性芳香族化合物のカチオン ラジカルの生成, 反応については多数報告されているが, ジカチオンに関しては少ない。一方，含硫黄非平面性芳 香族化合物における酸化還元挙動, カチオンラジカルお よびジカチオン生成についての報告例は殆ど見あたらな い。筆者らは，硫黄原子でナフタレン環のペリ位を架橋 した，ジナフト-1,5-ジチオシン(32)を合成した ${ }^{32)}$ 。32 の電極酸化は可逆で酸化電位は+0.7 V $\left(\mathrm{Ag} / \mathrm{Ag}^{+}\right)$であ る。これとは対照的に，他の 1,8-ジチオナフタレン誘 導体の酸化還元挙動は不可逆である ${ }^{33)}$ 。32 の濃硫酸溶 液の ESR スペクトル $(\mathrm{g}=2.0092)$ は, カチオンラジカル (33)の生成を示した。この溶液を加水分解すると，32 とスルホキシド(35)が生成比 $1: 1$ で得られた(スキーム 19)。これはカチオンラジカル 33 が不均化し 32 とジカ チオン 34 が生じ水と反応したものと考えている。

モノスルホキシド 35 は濃硫酸中で安定なジカチオン 34 を生成し, 高分解能 ${ }^{1} \mathrm{H},{ }^{13} \mathrm{C}-\mathrm{NMR}$ スペクトルおよび 同位体実験により確認した。即ち 35 の酸素原子を ${ }^{18} \mathrm{O}$
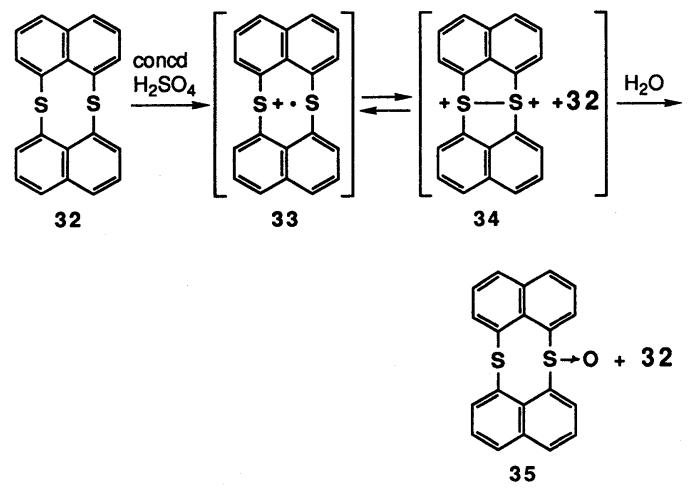

Scheme 19

で標識し, その濃硫酸溶液を加水分解すると ${ }^{18} \mathrm{O}$ は全く 検出されないことからジカチオン 34 の生成が支持され る(スキーム 20)。さらに 35 の $\alpha$ 位を重水素でラベル化 した $35 \mathrm{a}$ の濃硫酸溶液の加水分解生成物には酸素原子 の不均化が $1: 1$ で見られた(スキーム $20 \mathrm{a}) 。$

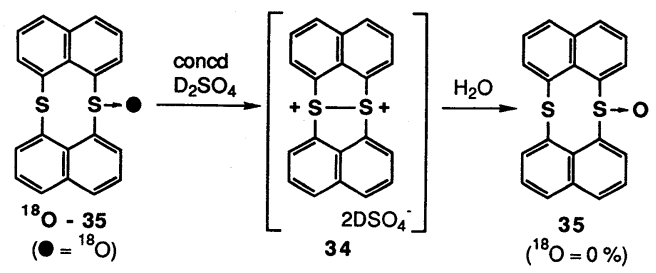

Scheme 20
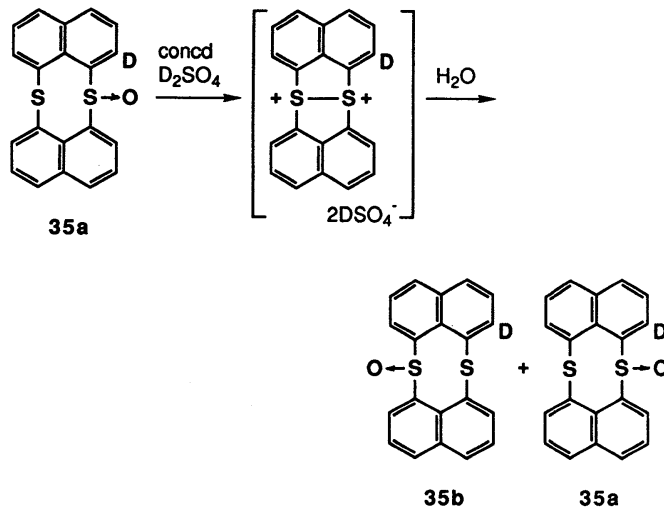

Scheme 20 a

32 は歪んだ立体構造をしているため硫黄原子上に生 じたカチオン種は, ナフタレン環の $\pi$ 電子による安定 化よりペリ位での S-S 相互作用による安定化の方が大 きいと考えられる。チアントレン $(\mathrm{Th})$ はその立体構造 
が可動的であることからカチオン種がベンゼン環のみに より安定化していることとは対照的である。

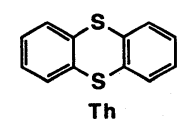

ところで, ビススルフィド 32 のセレン誘導体(36)は 濃硫酸には安定でカチオンラジカル(37)を生成し, セレ ノキシド(38)からは濃硫酸中ジカチオン(39)を生成す る。一方, スルフィド 32 のクロロホルム溶液は安定で あるが, セレニド 36 のクロロホルム溶液は自然光下, 空気中でセレノキシド 38 と数種の生成物を与える。こ れは36の低い酸化電位に依存していると考えている ${ }^{34)}$ 。

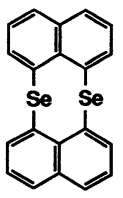

36

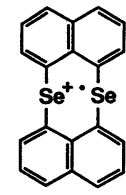

37

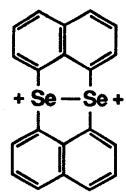

39

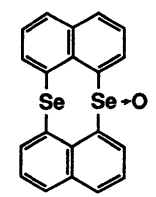

38
5. ジセレナジカチオン $\left(\mathrm{Se}^{+}-\mathrm{Se}^{+}\right)$

5.1. ジセレナジカチオンの生成と構造＼cjkstart環状ビスセ レニド，1,5-ジセレナシクロオクタン (1,5-DSeCO : 40) を合成し，CVによりその電気化学的挙動を調べた。40 の酸化ピークは+0.25 V( $\left.\mathrm{Ag} / \mathrm{Ag}^{+}\right)$にみられ，その酸化 還元過程は可逆であるのに対し， $n$-ヘキシルセレニド の酸化還元過程は不可逆でその酸化電位は $40 よ り も$ 約 $700 \mathrm{mV}$ 高い ${ }^{35)}$ 。40 の酸化電位の異常な低さおよび可逆 性は, アルキルセレニドとしては初めての例であり, 酸 化過程で生じる 40 の電子久損状態が著しく安定である ことを示す。即ち 40 は電極酸化の際に 2 個のセレン原 子の渡環相互作用により Se-Se 結合を生じカチオン種を 安定化すると考えられ，40が一段階で二電子酸化を受
けSe-Se 結合を持つジセレナジカチオンを生成すること を示している。実際 40 と一電子酸化剂 $\left(\mathrm{NOPF}_{6}\right.$ または $\left.\mathrm{NOBF}_{4}\right)$ を 2 当量用いる二電子酸化によりジセレナジカ

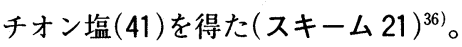

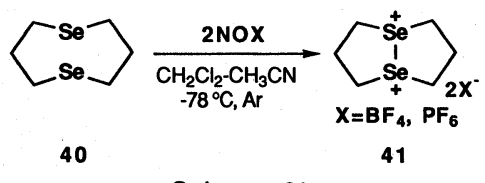

Scheme 21

${ }^{77} \mathrm{Se}-\mathrm{NMR}\left(\mathrm{CH}_{3} \mathrm{CN}\right)$ スペクトルは，セレニド 40 が $\delta$ 141.3(シングレット)であるのに対してジカチオン 41 は $\delta 806.5$ (シングレット)と非常に低磁場シフトしており ジカチオン構造を支持している。

ジセレナジカチオン塩 41 の X 線結晶解析より $\mathrm{Se}^{+}-\mathrm{Se}^{+}$ 結合距離は $2.38 \AA$ と通常の $\mathrm{Se}$ の単結合距離 $(2.34 \AA)$ で あり明らかにジカチオン構造である(図 8) 37)。また,こ の 8 員環は $\mathrm{Se}^{+}-\mathrm{Se}^{+}$に垂直な凝似的な鏡面をもち， chair-boat 形の立体配座をとっている。また，これはジ チアジカチオン塩(3)の歪んだ chair-chair 形の立体配座 とは異なっている。図 9 にはジカチオンの $\mathrm{Se}^{+}$と $\mathrm{BF}_{4}{ }^{-}$

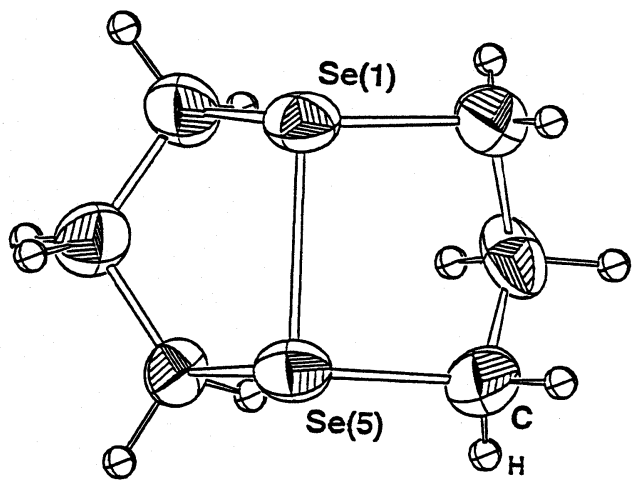

Fig. 8

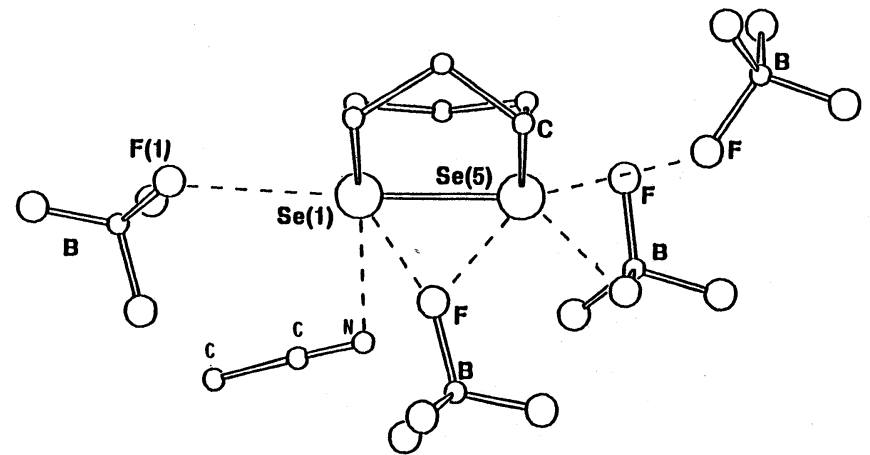

Fig. 9 
および $\mathrm{CH}_{3} \mathrm{CN}$ (再結晶溶媒)の間に見られるvan der Waals 半径の和より短い接触を示す。 $\mathrm{Se}^{+}$と $\mathrm{BF}_{4}{ }^{-}$の間

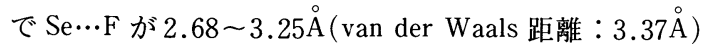
のものがあり, また, $\mathrm{Se}^{+}$と $\mathrm{CH}_{3} \mathrm{CN}$ の間で $\mathrm{Se} \cdots \mathrm{N}$ が $3.14 \AA$ (van der Waals 距離 : $3.45 \AA$ ) となっている。ジ セレナジカチオン塩として 41 は初めての例である。

他の中員環ビスセレニドからもジカチオン塩 (42, 43) を得ることができた。渡環相互作用の弱い 6 員環の 1,4-位間に $\sigma$ 結合を有するへテロ原子ジカチオンが安 定に単離できたのは, 43 が初めてである ${ }^{36)}$ 。

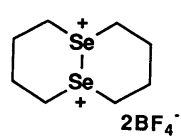

42

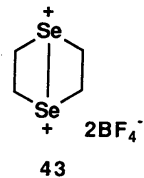

43

また，ジベンゾジセレナシクロオクタン (44)は CV よ り酸化還元過程は可逆で, 実際 44 と 2 当量の $\mathrm{NOPF}_{6}$ と の反応によりジカチオン塩 (45)を生成する。一方, ジフェ ニルセレニドとジベンジルセレニドの電極酸化は不可逆 であり，44の可逆性が異常であり，これは Se-Se 渡環 相互作用によると考えている ${ }^{38)}$ 。

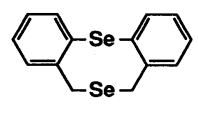

44

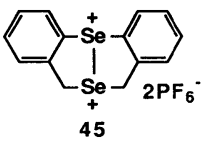

5.2. 反応性 ジセレナジカチオン塩 41 と置換ベン ゼンとの反応はジチアジカチオン塩 3 と類似性を示す

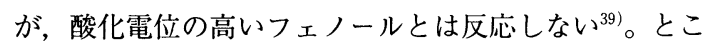
ろが，水にたいする反応性は著しく異なる。即ちジチア ジカチオンは水とただちに反応しスルホキシドを定量的 に与えるが, 41 は安定で水処理後も酸化㓮として働く。

ジカチオン塩 41 が一電子酸化剤として働く例として, フェノチアジン $(46)$ と 41 との反応をアセトニトリル中 で行い, UV スペクトルを測定したところ46のカチオ ンラジカル(47)が検出でき, 反応溶液を水処理したとこ ろ, フェノチアジン 5-オキシド(48)が得られた(スキー ム22)。これは46の酸化電位が 40 より低いために 46 が 41 によって一電子酸化された結果である。

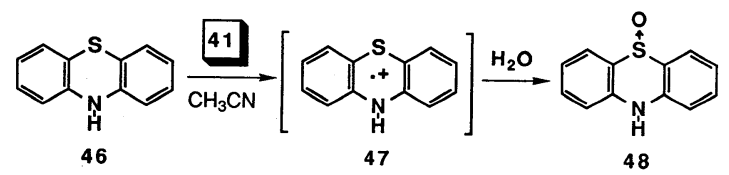

Scheme 22
41 とグリニャール試薬，パラトリルマグネシウムブ ロマイドとの反応では, パラ位置換体のセレノニウム塩 (49)が好収率で得られた(スキーム 23) $)^{40)}$ 。

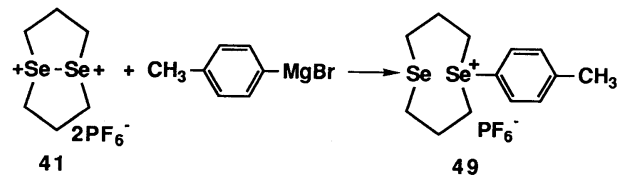

Scheme 23

ジカチオン塩 41 を $\mathrm{H}_{2} \mathrm{O}-\mathrm{EtOH}$ 中 $\mathrm{NaBD}_{4}$ と反応したと ころ還元生成物 40 が定量的に得られ，H-D 交換は全く 見られなかった $\left(\right.$ スキーム 24) ${ }^{40)}$ 。一方, ヒドラジンジ カチオン $(50)$ は $\mathrm{NaBD}_{4}$ との反応では中間体(51)を経由 し $\alpha$ 位が重水素化したアミン(52)を与える脱離-付加反 応が進行する(スキーム 25)。なお， 41 と $\mathrm{NaBH}_{4}$ との還 元反応は電子移動反応であると考えている。
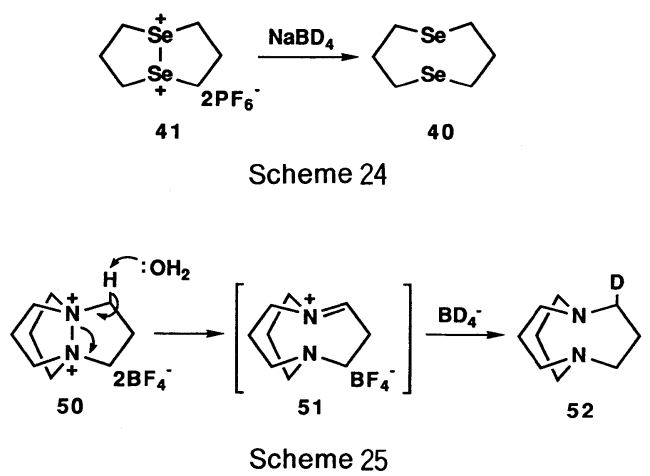

ジセレナジカチオン塩 41 の電極還元をアセトニトリ ル中 CV を用い行ったところその還元電位は+0.11 V $\left(\mathrm{Ag} / \mathrm{Ag}^{+}\right)$で可逆性を示した ${ }^{40)}$ 。ヒドラジンジカチオン 50 の電極還元は不可逆であり, 41 にみられる可逆過程 はへテロ原子ジカチオンでは初めての例である。

\section{6. 異種へテロ原子間での $\sigma$ 結合ジカチオン}

いままで述べたジカチオンは同種の原子であるが，二 つの異なるへテロ原子間でのジカチオン生成については 殆ど例がない。ここでは新規なジベンゾーセレナチオシ ン, 一セレナアゾシンについて主に述べる。

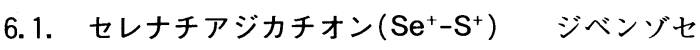
レナチオシン 53 の立体配座は, 二種類のコンホーマー, 即ち chair 形と boat 形が考えられる。そこで53の ${ }^{1} \mathrm{H}-\mathrm{NMR}\left(\mathrm{CDCl}_{3}\right)$ を測定したところ, メチレンプロトン は chair 形が $\mathrm{AB}$ カルテット $(\delta 3.87,5.05, \mathrm{~J}=14.5$ $\mathrm{Hz})$, boat 形がブロードシングレット $(\delta 3.72)$ として現 


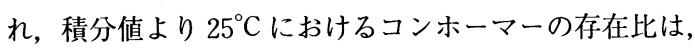
64(chair)：36(boat)である。さらに ${ }^{77} \mathrm{Se}-\mathrm{NMR}$ を測定し たところ $\delta 357$ (シングレット)と $\delta 386$ (シングレット) に2 本のピークが観測され, その積分值より ${ }^{1} \mathrm{H}-\mathrm{NMR}$ より求めたコンホーマーの存在比と良く一致した ${ }^{41)}$ 。

このように 53 は室温で 2 つコンホーマーが存在す るが, 53 を濃硫酸に溶解すると立体配座変換を起こし boat 形に変化する。つまり, ${ }^{1} \mathrm{H}-\mathrm{NMR} に$ にいてメチレン プロトンは非常に収束した $\mathrm{AB}$ カルテット ( $\delta 4.96$, $5.31, \mathrm{~J}=16 \mathrm{~Hz})$ が低磁場に, ${ }^{13} \mathrm{C}-\mathrm{NMR}$ に打いてもクロ ロホルム中での 2 本のメチレン炭素 $(\delta 32.8,42.1)$ が低 磁場シフトした 1 本のピーク $(\delta 50.5)$ として現われる。 ${ }^{77} \mathrm{Se}-\mathrm{NMR}$ では, 濃硫酸中で $\delta 944$ と, クロロホルム中 に比べ約 $600 \mathrm{ppm}$ も低磁場シフトして現れた。これは 明らかに, セレナチアジカチオン(56)の生成を示してい る(スキーム 26) $)^{41)}$ 。また 56 はセレノキシド 54 および スルホキシド 55 からも濃硫酸との反応により生成す る。56 は水と反応しスルホキシド 55 のみを与える。こ れとは対照的に 53 を $m \mathrm{CPBA}$ で酸化すると 54 と 55 の 混合物を与える。

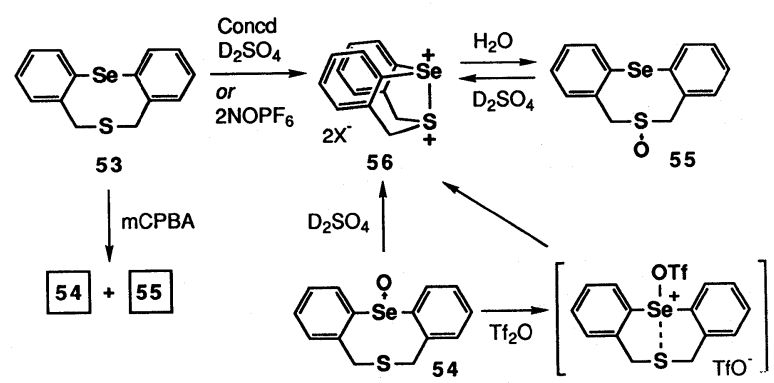

Scheme 26

セレナチオシンのジカチオン塩は, 53 と 2 当量の $\mathrm{NOPF}_{6}$ を用いる二電子酸化または, セレノキシド 54 と $\left(\mathrm{CF}_{3} \mathrm{SO}_{2}\right)_{2} \mathrm{O}$ との反応により得た。

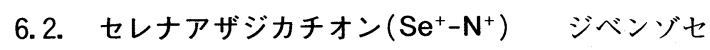
レナアゾシンのセレノキシド(57) と, $\left(\mathrm{CF}_{3} \mathrm{SO}_{2}\right)_{2} \mathrm{O}$ との 反応ではジカチオン塩 $(58)$ が白色結晶として得られる (スキーム 27)。58は ${ }^{77} \mathrm{Se}-\mathrm{NMR}\left(\mathrm{CH}_{3} \mathrm{CN}\right)$ に扔いて, セレ ノキシド 57 の $\delta 847$ より低磁場シフトし $\delta 1005$ に 1 本 のシングレットとして現われる ${ }^{42)}$ 。この塩は良い酸化剂 になる。
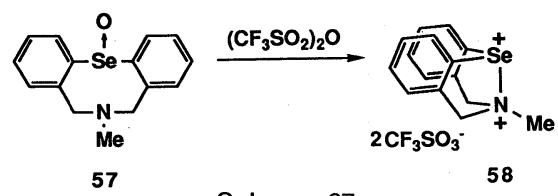

Scheme 27

\section{7. テルルのジカチオン}

テルルの環状化合物は相当する硫黄, セレン化合物より 合成が困難であるが，1,5-ジテルラシクロオクタン (1,5-DTeCO : 59), ジベンゾテルラチオシン (61)を各々 合成し, 二電子酸化によりジカチオン塩 $(60,62)$ を単離

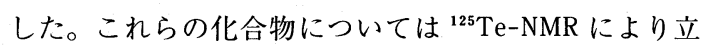
体配座およびジカチオン構造を確認した ${ }^{43,44)}$

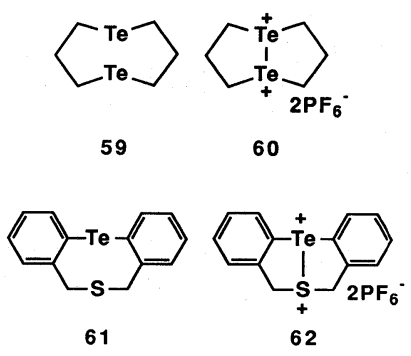

8. おわりに

以上，カルコゲン元素を 2 個以上含む中員環状化合物 の渡環相互作用によるカチオン種の安定化, ジカチオン 生成を主に概観した。本稿でとりあげたジカチオンはへ テロ原子間で $\sigma$ 結合を形成しており，今までにない新 規な化学種で, その化学的性質および物性面等まだまだ 未開拓の分野である。また，へテロ原子間での二中心三 電子結合によるカチオンラジカルと二中心二電子結合の ジカチオンの構造および反応性の違いなど, 今後の研究 課題のひとつである。さらに本稿で述べた環状トリスス ルフィド化合物群は特異な分子構造をしているため, 新 規な超原子価(hypervalent)化合物および高配位化合物 の合成も可能である。現在, 筆者らは multi-center ヘテ 口原子間でのポリカチオン生成抢よび異常原子価につい て研究を進めている。

この新しい分野と関連して, 平成 2 年度から, 文部省 科学研究費補助金「重点領域研究」 “有機典型元素化合物 の異常原子価” が広島大学理学部の秋葉欣哉教授を代表 として始まっている。益々の発展と多大の成果が期待で きる。

(平成 3 年 2 月 25 日受理)

\section{文献}

1) N.J. Leonard, Acc. Chem. Res., 12, 423 (1979)

2) R.W. Alder, ibid., 16, 321 (1983)

3) G.S. Wilson, D.D. Swanson, J.T. Klug, R.S. Glass, M.D. Ryan, W.K. Musker, J. Am. Chem. 
Soc., 101, 1040 (1979); M.D. Ryan, D.D. Swanson, R.S. Glass, G.S. Wilson, J. Phys. Chem., 85, 1069 (1981)

4) W.K. Musker, T.L. Wolford, P.B. Roush, J. Am . Chem. Soc., 100, 6416 (1978); W.K. Musker, Acc. Chem. Res., 13, 200 (1980)

5) K.-D. Asmus, Acc. Chem. Res., 12, 436 (1979)

6) F. Iwasaki, N. Furukawa, Acta Crystallogr., C 43, 80 (1987) ; S.M. Johnson, C.A. Maier, I.C. Paul, J. Chem. Soc., B, 1970, 1603; W.K. Musker, M.M. Olmstead, M.H. Goodraw, Acta Crystallogr., C 39, 887 (1983)

7) N. Furukawa, A. Kawada, T. Kawai, J. Chem . Soc., Chem. Commun., 1984, 1151

8) H. Fujihara, A. Kawada, N. Furukawa, Heterocyc. les, 24, 17 (1986)

9) H. Fujihara, A. Kawada, N. Furukawa, J. Org. Chem., 52, 4254 (1987)

10) H. Fujihara, N. Furukawa, J. Mol. Struct. (Theochem), 186, 261 (1989)

11) H. Fujihara, R. Akaishi, N. Furukawa, J. Chem . Soc., Chem. Commun., 1987, 930

12) H. Fujihara, A. Kawada, N. Furukawa, Gazz. Chim. Ital., 119, 617 (1989)

13) F. Iwasaki, Y. Toyoda, R. Akaishi, H. Fujihara, N. Furukawa, Bull. Chem. Soc.Jpn., 61, 2563 (1988)

14) H. Fujihara, R. Akaishi, N. Furukawa, Chem. Lett. , 1988, 709

15) H. Fujihara, R. Akaishi, N. Furukawa, unpublished results

16) A.W. Johnson, "Ylid Chemistry", Academic Press, New York, chap. 9, (1966)

17) H. Fujihara, R. Akaishi, N. Furukawa, J. Chem. Soc., Chem. Commun., 1989, 147

18) H. Fujihara, R. Akaishi, N. Furukawa, Bull. Chem. Soc. Jpn., 62, 616 (1989)

19) H. Fujihara, N. Furukawa, "Sulfur-centered Reactive Intermediates in Chemistry and Biology" NATO-ASI Series, Life Sciences, C. Chatgilialoglu, K.-D. Asmus, eds., Plenum Press, London, New York, 193, (1990)

20) H. Fujihara, J.-J. Chiu, N. Furukawa, J. Chem . Soc., Chem. Commun., 1986, 1359

21) F. Iwasaki, N. Toyoda, N. Yamazaki, H. Fujiha ra, N. Furukawa, Acta Cryst., C 46, 2154 (1990)

22) H. Fujihara, J.-J. Chiu, N. Furukawa, J. Am . Chem. Soc., 110, 1280 (1988)

23) H. Fujihara, J.-J. Chiu, N. Furukawa, Tetrahedron
Lett . , 30, 7441 (1989)

24) H. Fujihara, J.-J. Chiu, N. Furukawa, ibid . ,30, 2805 (1989)

25) H. Fujihara, J.-J. Chiu, N. Furukawa, unpublished results.

26) R.A. Hayes, J.C. Martin, "Sulfurane Chemistry", in "Organic Sulfur Chemistry, Theoretical and Experimental Advances”, eds., F. Bernardi, I.G. Csizmadia, A. Mangini, Elsevier, Amsterdam, Chap. 8 (1985)

27) H. Fujihara, N. Oi, R. Akaishi, T. Kawai, N. Furukawa, Heterocycles, 29, 441 (1989)

28) H. Fujihara, N. Oi, N. Furukawa, unpublished results

29) H. Fujihara, N. Oi, T. Erata, N. Furukawa, Tetrahedron Lett., 31, 1019 (1990)

30) H. Fujihara, R. Akaishi, N. Furukawa, ibid ., 30, 4399 (1989)

31) H. Fujihara, N. Nakata, R. Akaishi, N. Furukawa, unpublished results

32) H. Fujihara, J.-J. Chiu, N. Furukawa, Chem. Lett. , 1990, 2217

33) R.S. Glass, S.W. Andruski, J.L. Broeker, H. Firouzabadi, L.K. Steffen, G.S. Wilson, J. Am. Chem. Soc., 111, 4036 (1989)

34) H. Fujihara, M. Yabe, J.-J. Chiu, N. Furukawa, Tetrahedron Lett., in press

35) H. Fujihara, R. Akaishi, N. Furukawa, Chem. Lett. , 1990, 549

36) H. Fujihara, R. Akaishi, T. Erata, N. Furukawa, J. Chem. Soc., Chem. Commun., 1989, 1789 ; H. Fujihara, R. Akaishi, N. Furukawa, unpublished results

37) F. Iwasaki, M. Morimoto, M. Yasui, R. Akaishi, H. Fujihara, N. Furukawa, Acta Cryst., in press

38) H. Fujihara, Y. Ueno, J.-J. Chiu, N. Furukawa, J. Chem. Soc., Chem. Commun., in press

39) H. Fujihara, A. Nakamura, R. Akaishi, N. Furukawa, Chem. Lett., 1990, 393

40) H. Fujihara, R. Akaishi, A. Nakamura, N. Furukawa, Tetrahedron Lett., 31, 6375 (1990)

41) H. Fujihara, H. Mima, J.-J. Chiu, N. Furukawa, ibid. , 31, 2307 (1990)

42) H. Fujihara, H. Mima, T. Erata, N. Furukawa, J. Chem. Soc., Chem. Commun., 1991, 98

43) H. Fujihara, T. Ninoi, R. Akaishi, T. Erata, N. Furukawa, Tetrahedron Lett., in press

44) H. Fujihara, Y. Takaguchi, J.-J. Chiu, T. Erata, N. Furukawa, submitted 